\title{
Who's afraid of Local Agenda 21? Top-down and bottom-up perspectives on local sustainability
}

\section{Luísa Schmidt}

Institute of Social Sciences - University of Lisbon (ICS-UL),

Aníbal de Bettencourt, 9, 1600-189 Lisbon, Portugal

Fax: 351217940274 E-mail: schmidt@ics.ul.pt

\section{Joaquim Gil Nave}

University Institute of Social Sciences and Business Studies (ISCTE), Das Forças Armadas, Ed. ISCTE, 1649-026 Lisbon, Portugal

Fax: 351217903938 E-mail: Joaquim.Nave@iscte.pt

\section{João Guerra*}

Institute of Social Sciences - University of Lisbon (ICS-UL), Aníbal de Bettencourt, 9, 1600-189 Lisbon, Portugal

E-mail: Joao.Guerra@iscte.pt

${ }^{*}$ Corresponding author

\begin{abstract}
Local Agenda 21 is essentially a process of democratic practicing, insofar as it involves sharing political competencies in decision making by the local authorities, and the mobilisation of all citizens and civil society organisations in the process. It is, thus, a course of action in which the willingness and openness of local political leaders is as important as the ability of citizens to take the initiative of learning about and getting involved in local public life. Unfortunately, there are no more than twenty LA21 processes running in Portugal, and most of them do not fulfil all the parameters required This paper discusses some hypotheses on the lack of success of LA21 in Portugal, which are related to structural political conditions for local governance and public participation. Resorting to some surveys on environmental policy issues (applied to both the municipal leaders and the population), the aim is to characterise the trends of mobilisation on local sustainability in Portuguese society, particularly with regard to the citizenry and local administrations.
\end{abstract}

Keywords: Local Agenda 21; sustainable development; citizenship; Portugal.

Reference to this paper should be made as follows: Schmidt, L., Nave, J.G. and Guerra, J. (2006) 'Who's afraid of Local Agenda 21? Top-down and bottom-up perspectives on local sustainability', Int. J. Environment and Sustainable Development, Vol. 5, No. 2, pp.181-198.

Biographical notes: Luísa Schmidt is a Sociologist and Senior Researcher at the Institute of Social Sciences - University of Lisbon. She particularly works on studies on Sociology of the Media and Environmental Sociology. Since its foundation in 1995, she coleads the OBSERVA - Observatório Permanente de Ambiente, Sociedade e Opinião Pública, a research programme 
on environment, society, and public opinion. She is also a member of the National Council for the Environment, an independent agency of the administration in charge of monitoring environmental policy initiatives and legislation. She is also a well known environmental journalist at Expresso, a top weekly newspaper in Portugal.

Joaquim Gil Nave is a Sociologist and Senior Professor at the Instituto Superior de Ciencias do Trabalho e da Empresa - ISCTE (University Institute of Social Sciences and Business Studies). He runs courses on environmental sociology and has codirected the OBSERVA - Observatório Permanente de Ambiente, Sociedade e Opinião Pública (a research programme on environment, society, and public opinion) since its foundation in 1995.

João Guerra is a Sociologist and Researcher in ICS-UL (Institute of Social Sciences - University of Lisbon). Since 1998 he has participated in several research projects including studies of Portuguese environmental values; sustainability, civic participation and governance, environmental education, etc.

\section{Primary conditions for Local Agenda 21 in Portugal}

The 10th principle of the Declaration of Rio - 1992 stresses 'social participation' as a primary condition for sustainable development. This principle is gaining priority nowadays. On the one hand, the making of sustainable development calls for a collective commitment by the citizens. They play an important role in demanding and supporting prosustainability initiatives by political and economic authorities (a bottom-up process). On the other hand, it calls for the openness of decisionmakers to social movements and collective action; that is, in promoting participation and collective action by groups from within civil society (a top-down process). Cooperation, mutual acceptance and trust are key words in sustainable development.

From this point of view, political will and selfdetermination by local administrations, particularly by the leaders elected for municipalities, is a crucial path for the success of initiatives for local sustainability, as demonstrated by the case of Local Agenda 21 (LA21) processes all around the world after the Earth Summit of 1992 (Agenda XXI). The importance of the role of local administrations in these processes is widely emphasised by all United Nations' organisations for the environment and development. The Agenda XXI document argues in the first paragraph of Chapter 28 that

\footnotetext{
"as the level of governance closest to the people, they (local administrations) play a vital role in educating, mobilising, and responding to the public to promote sustainable development." (UNCED, 1992)
}

The International Council for Local Environmental Initiatives defines Local Agenda 21 as a

"participatory, multistakeholder process to achieve the goals of Agenda 21 at the local level through the preparation and implementation of a long-term, strategic plan that addresses priority to local sustainable development concerns." (ICLEI, 2002, p.6) 
The efforts of both the governing and the governed are critical for achieving initiatives that aim to launch sustainable development. From this point of view, Local Agenda 21 is an opportunity to provide a decisive impetus to this endeavour.

This is why late comer democracies tend mostly to meet the lowest levels of implementation in what concerns participatory processes for local sustainability. Essentially, difficulties relate to both the governing and the governed. While, the former persist being embarrassed in dealing with public participation, the latter are still unresponsive to attempts of selforganisation so as to allow and enhance participation. This is clearly the case of Portugal, whose particular status in the EU context (a status well behind countries with long consolidated democracies such as the European Community founders) makes it to rank much closer to former Eastern block countries, where democracy just started in the aftermath of the fall of the Berlin Wall in 1989.

As a matter of fact, Portugal was ruled by a dictatorship during the larger part of 20th century, opening to a new democratic path with the Revolution of April 1974. Local government gained wide political autonomy, being since then directly elected by local citizens and no more nominated by the top government in Lisbon. Certainly, in comparison with Eastern Europe countries, there are important distinctions to consider. In the first place, the Portuguese had been ruled by a right wing, anticommunist dictatorship (not a Communist one). Moreover, with its Southern Europe character, Portugal shares the kinds of characteristics that Mediterranean cultures convey to democratic practices and political systems. ${ }^{1}$ In spite of this, there is a curious set of similarities to be found between Portugal and the former Eastern block countries, where democracy has been a recent process within the context of weak economies.

This is why the functioning of both civil society organisations and government institutions, at either central or local level, must be viewed in context; that is, as a result of recent structural changes. In a way, though democracy permits conditions for increasing civic mobilisation and participation, vestiges of ancient authoritarian regimes still persist. In the case of Portugal, after more than three decades, there is still very modest evidence of public participation, while political institutions still display striking trends of centralism. Decisionmakers and decision making organisations firmly resist to more participatory forms of interaction with the citizenry beyond formal electoral mechanisms. Adding to the lack of tradition in publicly discussing community problems, the rising of practical obstacles within the administration to inhibit public access to information is also common ground.

In this context, Local Agenda 21 is a good test to the maturity of democracy. Basically, it may represent a new opportunity to enhance democratic practices, since it requires the direct involvement of the citizens and of civil society organisations; it compels changes in governance and administration; it forces to open access to information by administrations; finally, it promotes wide and new forms of listening to the people at the local level. As a matter of fact, analysis of the implementation of Local Agenda 21 in Europe, according to the ICLEI survey (2002), showed that the number of LA21 cases increased where democracy has been established for a much longer time and is anchored in much stronger economies (see Figure 1).

Listing the countries by the number of LA21 cases (see Figure 1), we only find former Eastern block countries behind Portugal in the ranks, and some of them even show as much more LA21 active, as the case of Estonia, Slovakia, and the Czech Republic. Moreover, the number of LA21 cases seems to vary according to the degree of consolidation and maturity of democracy. Late comer democracies are more apt to lack 
reforms in administrative structures and methods, as well as in political institutions and democratic practices. Thereby, local sustainability seems to have to face more difficulties and obstacles in order to involve and mobilise social actors and local administrations.

Figure 1 Local Agenda 21 cases in Europe (ICLEI, Second Survey, 2002)

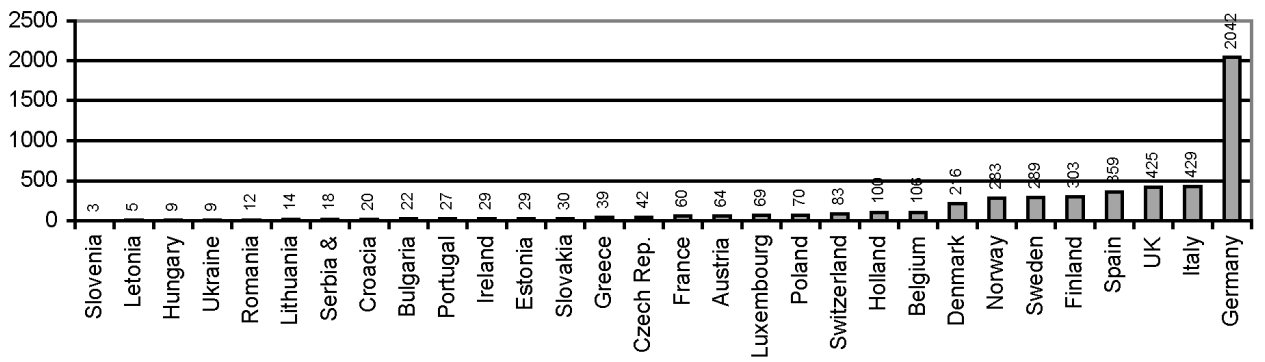

Source: Schmidt et al. (2005)

However, these trends also vary according to the economic conditions of each country. Those enjoying stronger and more advanced economies, independently of how recent democracy is in the country (see the case of Spain), come first in launching processes of local sustainable development, if only because they are more advanced in basic development problems at the local level.

Quoting another study on LA21 (see Table 1), we can see that Nordic countries - particularly Sweden - have practically fully achieved LA21, while in the south, the process has just begun. In circumstances, Portugal is obviously placed outside the table, firstly, because it was not included in the study, and secondly, because LA21 processes are only emerging. Actually, while most countries have officially started LA21 along the 1990's, environmental authorities in Portugal have only last year (2004), prepared a National Strategy for Sustainable Development (NSSD), assuming for the first time the intension of the state for launching and spreading out LA21.

Table 1 Implementation of Local Agendas 21 in 12 European countries ${ }^{2}$

\begin{tabular}{|c|c|c|c|c|}
\hline \multirow{3}{*}{$\begin{array}{l}\text { Percentage of } \\
\text { municipalities covered } \\
\text { by a Local Agenda } 21 \\
\text { or a similar process }\end{array}$} & \multicolumn{3}{|c|}{ Beginning of LA21 process and growth tendency } & \multirow{2}{*}{$\begin{array}{l}\begin{array}{l}\text { Situation in } \\
\text { Portugal }\end{array} \\
\text { In } 2004 \\
\end{array}$} \\
\hline & \multicolumn{3}{|c|}{ In 1999} & \\
\hline & 1992-1994 & $1995-1996$ & $1997-1999$ & $2002-2004$ \\
\hline More than $60 \%$ & Sweden $\mathbf{y}$ & Denmark $\lambda$ & & \\
\hline \multirow[t]{2}{*}{ From $20 \%$ to $60 \%$} & UK $\mathbf{y}$ & Finland $\leftrightarrow \rightarrow$ & & \\
\hline & Holland $\leftarrow \rightarrow$ & Norway $\boldsymbol{\lambda}$ & & \\
\hline \multirow[t]{4}{*}{ Less than $20 \%$} & & Austria $\pi$ & France $\bullet \rightarrow$ & \\
\hline & & Germany $\leftrightarrow \rightarrow$ & Italy $\boldsymbol{\nearrow}$ & \\
\hline & & & Spain $\pi$ & \\
\hline & & & Ireland $\boldsymbol{\lambda}$ & \\
\hline Less than $10 \%$ & & & & Portugal $\bullet \rightarrow$ \\
\hline
\end{tabular}

Source: Adapted from Lafferty (2001) 
The horizontal arrow means that Portugal is still lacking direct efforts and initiatives from public administration aiming at the implementation of LA21, which further reflects the lack of influence and articulation of environmental issues in political agendas (a factor important in determining the advancement of LA21 in other countries). This also means both the lack of LA21 initiatives at the local level and the shortage of attention devoted by political parties (from right to left wing) to the issue, which is practically ignored within party cultures of all wings. Moreover, there is no policy initiative or coordinated programme for the implementation of LA21s at the supramunicipal level. Curiously, recent initiatives of the kind are emerging in border regions as a consequence of cooperation agreements under the lead of Spanish municipalities, as the case of Eixo Atlâtico and Raia 21. ${ }^{3}$ Nevertheless, both in the crossborder cooperation cases and in a very few cases around the country, where more active local leaders are occasionally found, the profile of the respective LA21s is very poor.

Thus, diverging from the majority of European countries in Table 1, the case of Portugal is characterised at the state level by

- lack of support and promotional framework by the government at the central level (there is no state entity in charge of leading the promotion and implementation of LA21)

- lack of stimulus, technical support, and campaigns for spreading out LA21 initiatives over the territory

- lack of financial or other kinds of resource incentives.

Let us now look more closely at some data on the implementation of LA21 in Portugal, firstly stressing the perspective of local leaders and then the perspective of the citizenry.

\section{Local government, public participation and Local Agenda 21}

The case of other southern countries (e.g., Spain, France) demonstrates how the personal zeal of local authorities and leaders is a critical factor for the adoption and the success of LA21. For instance, it is a decisive factor for

- the capacity and efforts to mobilise resources

- the projection and visibility of LA21 programmes within local politics

- the enhancement of institutional legitimacy resulting from direct efforts of the local government leadership

- the ability to cause disturbances in local 'politics as usual', that is, ability to open to new values, new areas of intervention, and new methods of action

- achieving higher levels and a wider range of influence, which the local administration department would find difficult to achieve on its own.

In order to know to what extent Portuguese Mayors are favourable towards, or plan to launch processes of LA21 in their municipalities, we resort to a survey which we directly applied to a wide sample of Mayors. Let us have a look at some results of the survey. 
Local administration leaders were asked about who in the first place has the responsibility for implementing Sustainable Development at the local level. As shown in Figure 2, the majority (more than 57\%) agree in assuming themselves (that is, the municipality) as the responsible in the first place for the task. They claim to be closer and to know better what the local problems are, and consequently they feel themselves better positioned and more informed to address them. However, around $28 \%$ assign the main responsibility for implementing Sustainable Development at the local level to the government, since from their point of view it is the entity which is in a better position to provide technical means and resources for the task. Only $8.5 \%$ show an inclusive view of Sustainable Development so as to consider that it is a task for 'everyone'.

Figure 2 Who has the responsibility for implementing local sustainable development?

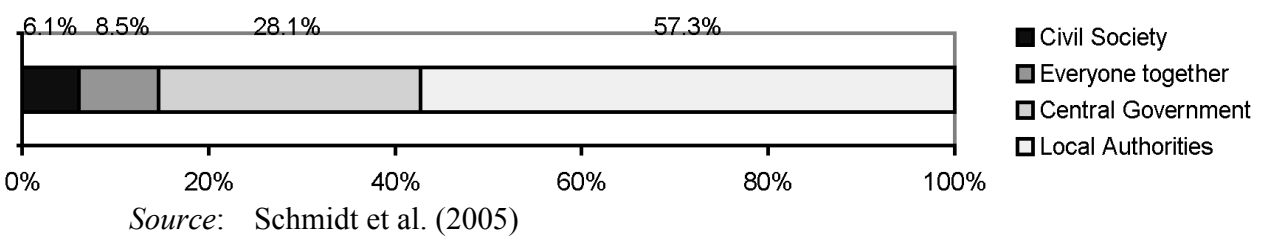

Another question asked how they heard about Local Agenda 21 for the first time (Figure 3 ). Around $38 \%$ of the mayors said that the media was their main source of information on the issue (though the expectation is that local leaders should themselves be the source, not the target, of media information on the issue). Only $28 \%$ said they heard about it for the first time from institutional sources (governmental organisations, national and EU legislation, and so on). Some (20,7\%) confessed that they really do not know at all what Local Agenda 21 is about. Some others heard about it at congresses and conferences they had participated in $(14.6 \%)$, or they received information on the issue in talks with other local leaders $(13.4 \%)$. Still others got this information from technical departments of municipalities $(11 \%)$, and finally from books, reviews and Internet (around 9\%).

Figure 3 How did you learn about Local Agenda 21?

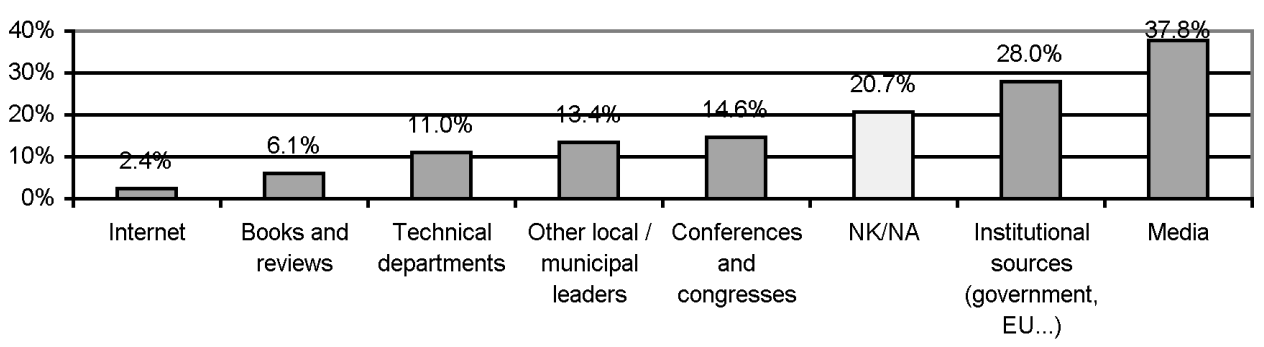

Source: Schmidt et al. (2005)

The definition of Local Agenda 21 proposed by the ICLEI says that it is a participatory process, mobilising all interests and groups at the local level in the implementation of a plan aiming at sustainable development, in consideration of its three dimensions (social, economic and environmental). Our survey, however, registered only $10 \%$ of mayors whose idea of Local Agenda 21 fits the main principles of the standard definition (see Figure 4). On the contrary, $44 \%$ of them show that they practically ignore what the 
issue is all about. Others tend to simply reduce it to an environmental issue, while the standard definition stresses this dimension to be as important as the economic and social ones. At the same time, they also relegate the civic and participatory dimension of the process to a secondary level of importance, while it is stressed as a priority and an indispensable element of LA21 by standard definitions.

Figure 4 How would you describe a Local Agenda 21?

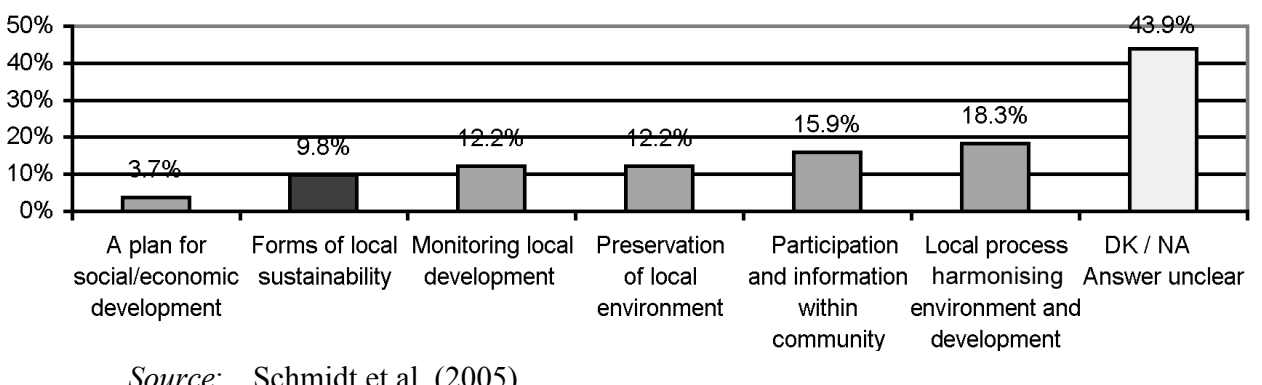

On difficulties found by local leaders in Portugal in implementing local processes of Sustainable Development (SD), they mostly refer to the insufficiency of financial means and resources $(28 \%)$ and the scarcity of human resources $(11 \%)$, which come up as the main obstacles (see Figure 5). Further difficulties are related again to policy making at the central level and by the government of Portugal: the lack of a national programme able to map out a strategy and to support SD initiatives (around 13\%), the lack of coordination between the different spheres of power and policy-making (15\%), and lastly the lack of competency and decision making empowerment by municipalities. Or rather the local leaders resent the lack of articulation between central and local governments, as if the former did not recognise the latter as good interlocutors to which resources and competencies should be ascribed.

Figure 5 The most important obstacles to local sustainable development

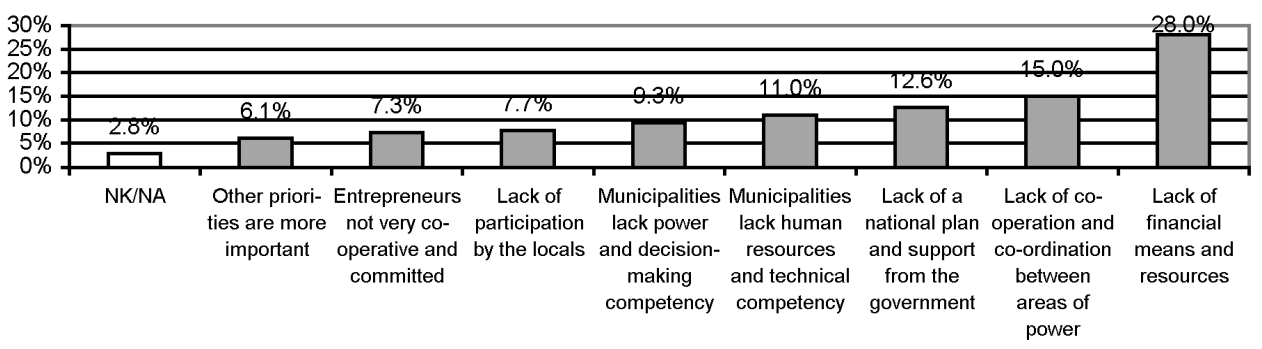

Source: Schmidt et al. (2005)

Analysing the difficulties in the implementation of sustainable development stressed by local leaders according to our survey and that of the ICLEI Survey (2001), ${ }^{4}$ one finds practically the same list of difficulties (lack of financial and technical resources, lack of a national programme, etc.) and they are expressed with the same intensity. Only the 'lack of participation or lack of interest from the locals' receives less attention from the Portuguese local leaders, which is consistent with their underestimation of the social dimension in their own definition of sustainable development (Figure 6). 
Figure 6 The most important difficulties for the implementation of sustainable development

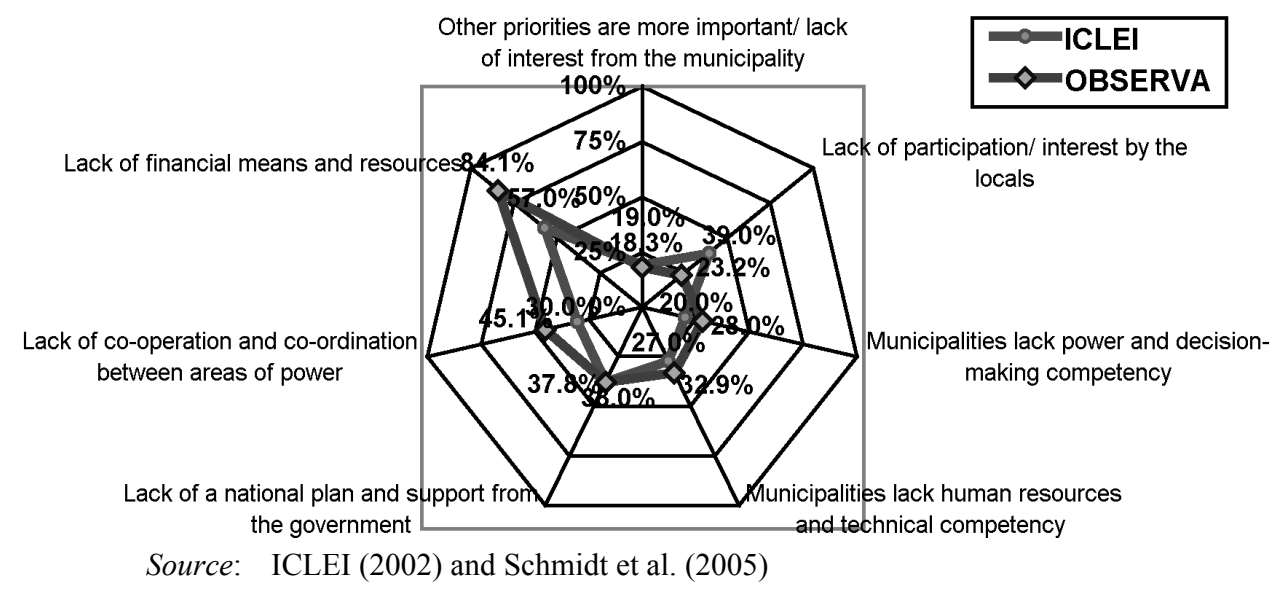

The next question included in our survey to local governors asked about the measures they would like to suggest aiming at overcoming difficulties in the implementation of sustainable development at the local level. The choice of a wide majority of local leaders falls upon the need for more financial resources. Only one third of the Mayors demand the allocation of more technical resources and qualified personnel, while another third addressed the decentralisation of powers and competencies. About $20 \%$ called for better coordination of public policies, while $17 \%$ called for the creation of a national programme of implementation. Finally, around 16\% suggested further policy initiatives aiming at increasing the levels of public awareness and information as a means to enhance mobilisation of local populations (Figure 7).

Figure 7 Initiatives for overcoming obstacles to the implementation of sustainable development (spontaneous answer)

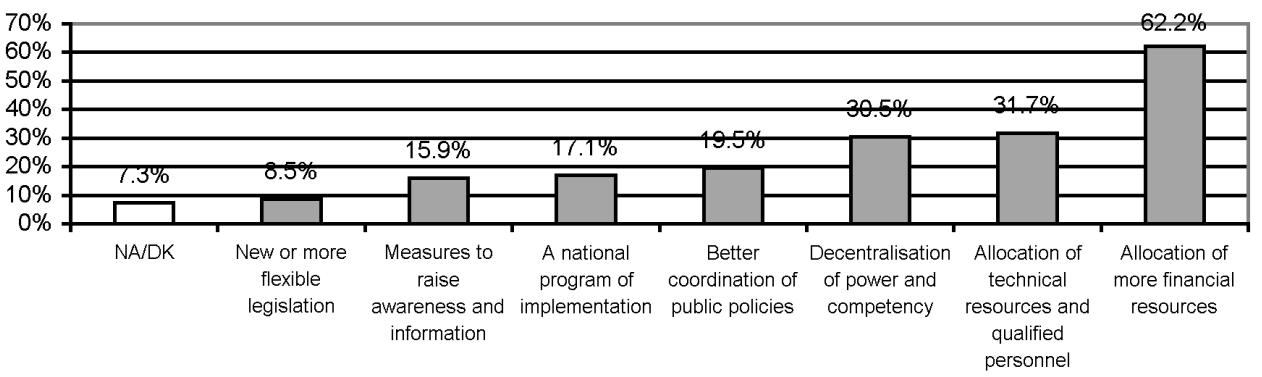

Source: Schmidt et al. (2005)

However, when we asked about the role they reserve to local populations' in decision making processes, only $30 \%$ of the Mayors declare their unconditional acceptance of the principle of public participation in decision making by local citizens, while $31 \%$ claim that the complexity of issues makes it difficult for the people to play a more active role in decision making. Pushing this trend to the limits, about $40 \%$ of the Mayors in the sample maintain the opinion that the decision making processes should be reserved for those specifically elected for the purpose, though resorting to technical assistance (Figure 8). 
In what concerns the Mayors' evaluation of current levels of participation in local politics by the local citizens, $45 \%$ declare that it is very low or nonexistent, while only $47 \%$ consider it to be at the average level. Only $4 \%$ think it is high. This confirms what we said previously about the negative view of local political leaders on their local citizens' ability to participate in decision making on collective issues (Figure 9). They really feel that citizens are, in general, illinformed and unprepared to play a more active role in local governance. That the Portuguese are not very participative in public affairs is a widely accepted assertion, but there is no consensus about the reasons for the same.

Figure 8 Role ascribed to participation of local populations in decision making processes

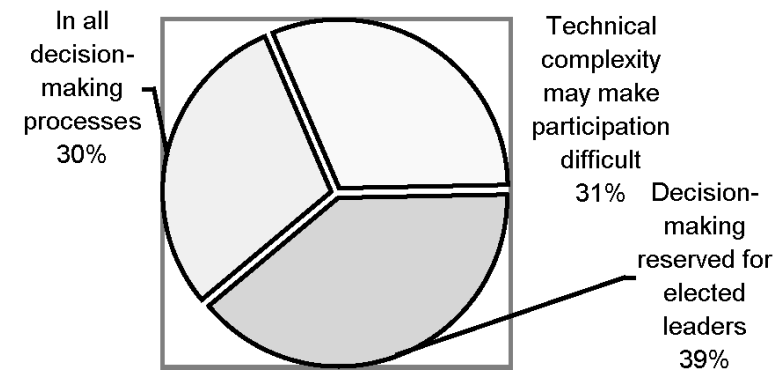

Source: Schmidt et al. (2005)

Figure 9 According to your own experience, the participation of the locals in SD processes has been

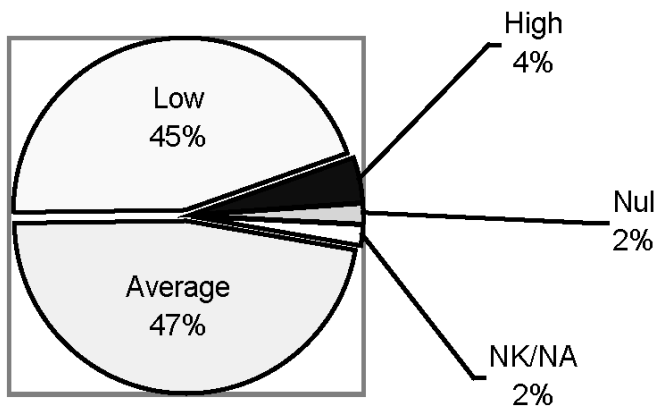

Source: Schmidt et al. (2005)

Let us have also a look at the opinion of Portuguese local leaders about the access by local populations to information held by municipal departments. In general, as we can see in Figure 10, all participants in the survey showed wide openness to making information available to citizens. Actually, $56 \%$ of the answers stand for making the information held by municipal departments available to the public without restrictions. However, $21 \%$ admitted that some information should not be made openly available, and $16 \%$ argued that only information relevant to the applicant should be available to him.

In spite of a couple of local leaders confessing to some reserve, one has to find that this openness is somewhat surprising, maybe just «politically correct», given the signs suggesting that on the contrary, a firm resistance to open access to administrative data still persists in public services, particularly in the case of local administrations. For instance, there is an increasing number of demands by the citizens on the Comissão de Acesso a Documentos Administrativos (Committee for the Access to Administrative 
Documentation - CADA), an independent public agency that operates in Parliament, supervising legal compliance in access by the citizenry to data and information held by the administration.

Figure 10 Willingness to provide information independently of legal obligations

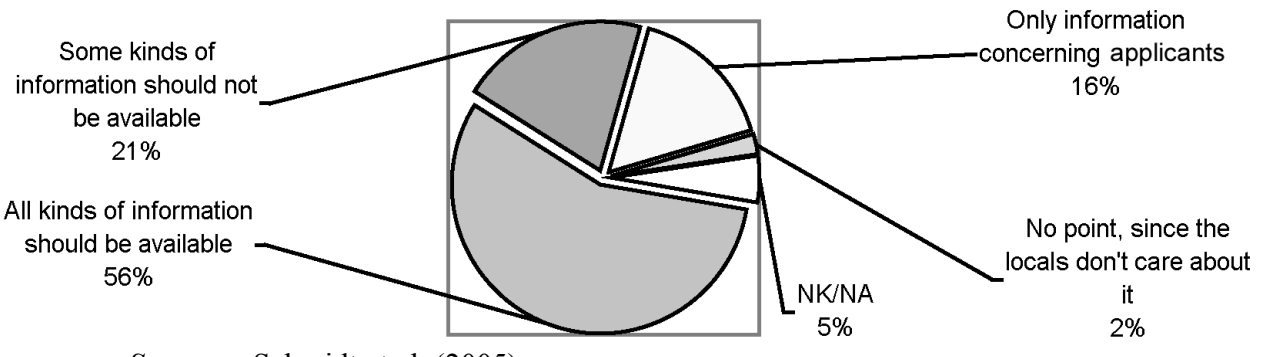

Source: Schmidt et al. (2005)

Since Mayors said they find the levels of public participation in sustainable development issues very low, what measures would they recommend for motivating and promoting civic involvement of local populations? As shown in Figure 11, forums, meetings, and assemblies gathering the locals are the mechanisms mostly cited in answers aiming at stimulating participation (45\%), followed by campaigns to raise and spread awareness on the issue (28\%). The remaining answers mainly address the direct contact with the locals $(13 \%)$, concrete programmes to specifically inform the people about each project/problem/issue (11\%), launching partnerships $(10 \%)$, and dissemination of information either through the media $(9 \%)$ or through door to door distribution of leaflets $(9 \%)$.

Figure 11 What mechanisms would you consider appropriate for motivating public participation?

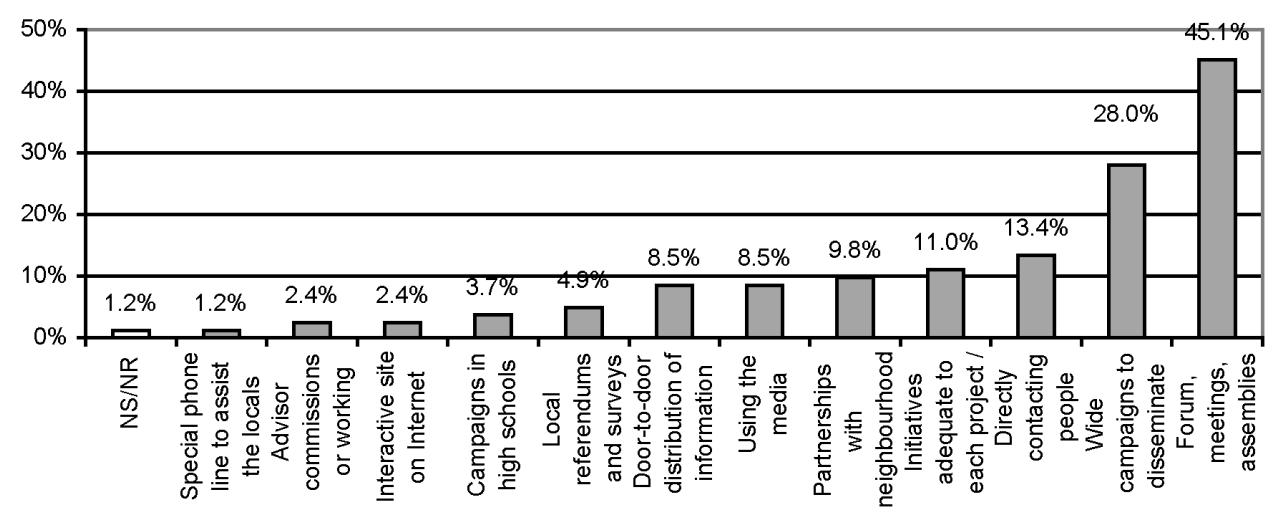

Source: Schmidt et al. (2005)

\section{Citizens and participation in Local Agenda 21}

Let us now focus on civil society and look at how participation is processed by the citizenry. Resorting to comparative data from several European countries (e.g., the European Values Study (EVS) and the European Social Survey (ESS)) it is easy 
to confirm the low levels of public participation in Southern Europe. This is the case of Portugal and, to a lesser extent, also of Spain. However, the same can be said about former Eastern block countries, in contrast to the committed activism found in the Northern countries, particularly Sweden and Holland (Figure 12).

Figure 12 Activism and voluntary work in associations in Europe

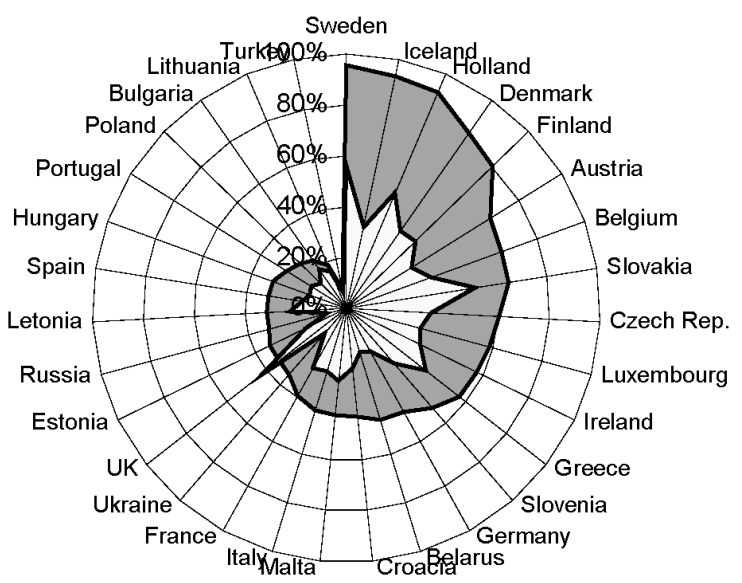

Source: Jowell et al. (2003)

\section{口Activism in associations \\ $\square$ Voluntary \\ work}

This deficit of participation seems characteristic of all kinds of associations. In the Portuguese case, however, it is accentuated in the case of organisations involved in community problems and collective issues, although participation is guaranteed in the case of sports/recreational and religious associations. Activism and voluntary work in other kinds of associations, even those more conventional or traditional, such as trade unions and professional groups, do no appear to receive the preference of the Portuguese in comparison to other nations (Figure 13).

Figure 13 Activism and voluntary work in associations in Portugal

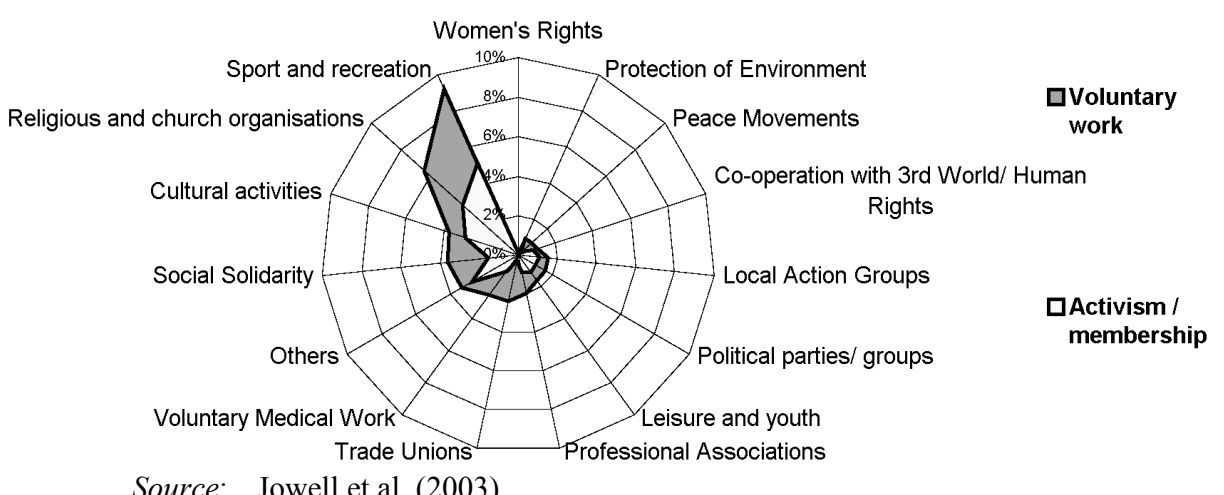

The aim of this study, however, is to understand how citizens do relate to issues of Local Agenda 21. Let us have a look at how Europeans respond to questions about their participation in local action groups and associations for the protection of the environment. 
Different social realities and, of course, different democratic paths and traditions tend to differentiate the civic behaviour of citizens. Even so, maybe the recent history of political authoritarianism is not enough to explain and justify everything. For instance, the cases of Slovakia, Slovenia and the Czech Republic tend in this case to join the group of countries most dedicated to participation and activism in associations. However, in the case of the Portuguese, nothing changes significantly, since they keep fitting to the group of the less motivated on these issues, thereby joining most countries from the former Eastern block to form the group under $1.5 \%$ of citizens declaring willingness to take part in local action groups. Populations appear, thus, to be excluded from collective action aiming at defending or protecting collective interests, even at a scale closer to daily and community life. At the other extreme of the scale, we find again the Swedish, who play the most active role at the local level and with Local Agenda's 21 succeeding in municipalities all over the country (Figure 14).

Figure 14 Participation in local action groups in Europe

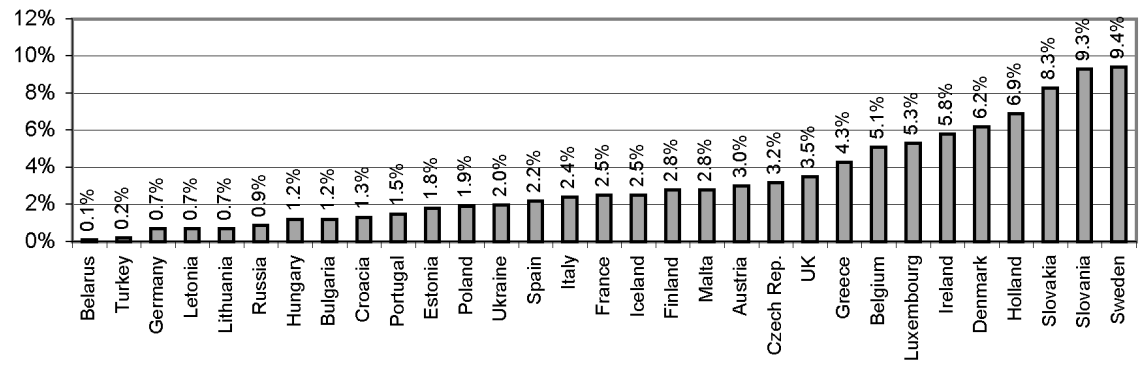

Source: Jowell et al. (2003)

When we look at statistical indicators concerning participation in associations for the protection of the environment, as one might guess, the situation does not change substantially. Again, the Portuguese and former Eastern block countries remain together at the end of the scale (with less than 1\% of participation). On the opposite side, there are again, the North European nations, joined again by the Dutch, who are also very active in groups for the protection of the environment (45\%). On the contrary, all indicators considered, Portugal and most of the Eastern European countries persistently show lower levels of participation and involvement within community collective interests (Figure 15).

Figure 15 Activism in Associations for the Protection of the Environment in Europe

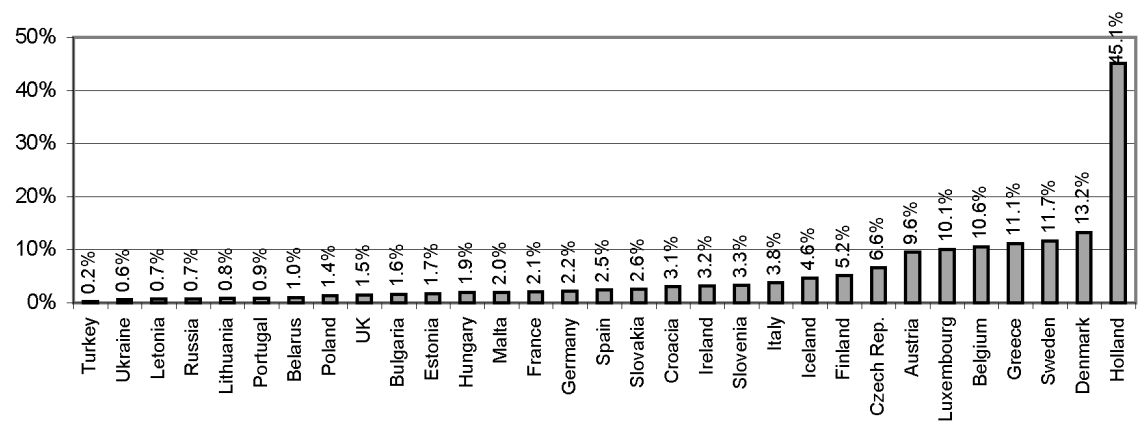

Source: Jowell et al. (2003) 
Let us now have a look at another survey, which sought to find out the profile of what one may consider softer forms of political participation. For instance, Figures 16 and 17 gather some information on the percentage of citizens who over the last 12 months took the initiative to directly contact a politician (at either the central or local level) or to sign a petition on whatever the issue.

Figure 16 Citizens who have contacted a politician over the last 12 months

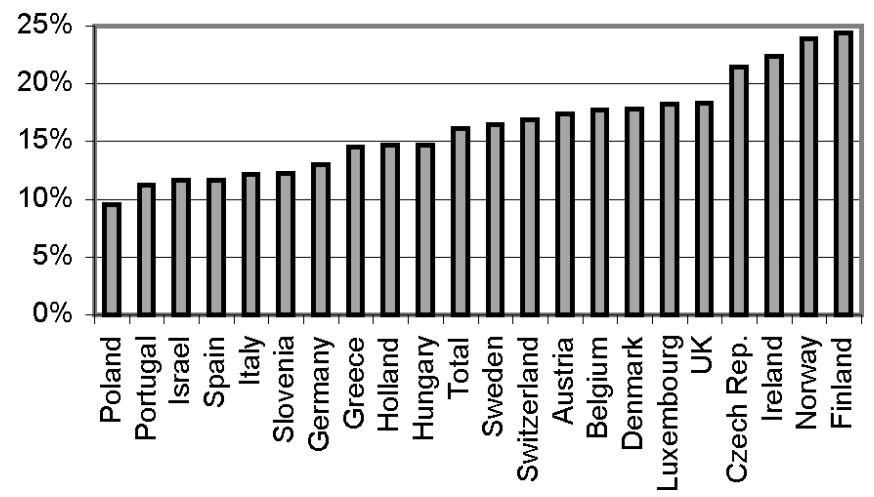

Source: Halman (2003)

Figure 17 Citizens who have signed a petition over the last 12 months

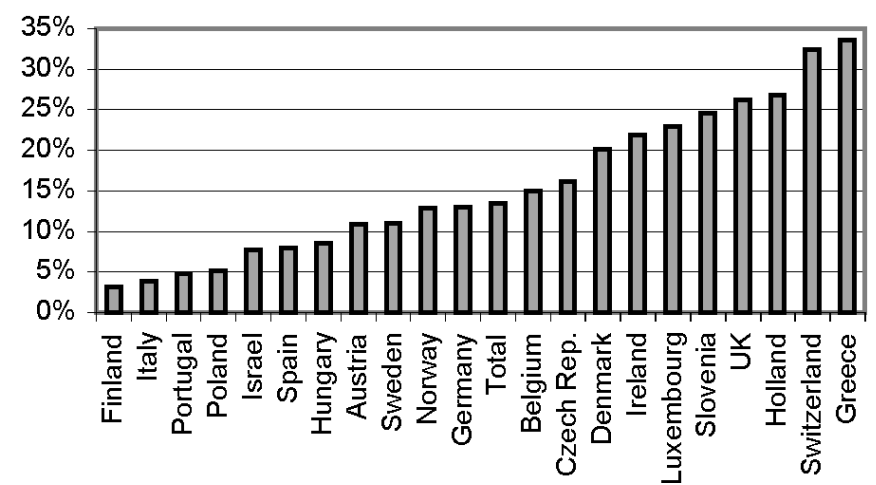

Source: Halman (2003)

Once again, despite some changes concerning the other countries in the tables, the Portuguese still maintain the less active posture, since relatively few citizens had actually taken any of the actions considered. As a matter of fact, by comparison to their fellow European citizens, individual initiatives to contact a politician directly to express or talk about collective problems seem to be very scarce, and even fewer had signed a petition. And the same is true for the case of other ad hoc actions like 'participating in demonstrations' or 'boycotting a product for civic reasons' - actions that once more relegate the Portuguese to the last place in the rank of European people.

It seems that the Portuguese are not very enthusiastic towards participation in politics or maybe they do not trust politics and politicians very much. In Figure 18 there is an indicator on the distance felt by the Portuguese towards politics in general. This time, they are joined by their Spanish neighbours, the Hungarians and the Czechs, but they still 
remain among the less active European citizens in what concerns participation in political parties or other kinds of groups mobilising on political issues.

Figure 18 Do you see yourself actively participating in a political issue group?

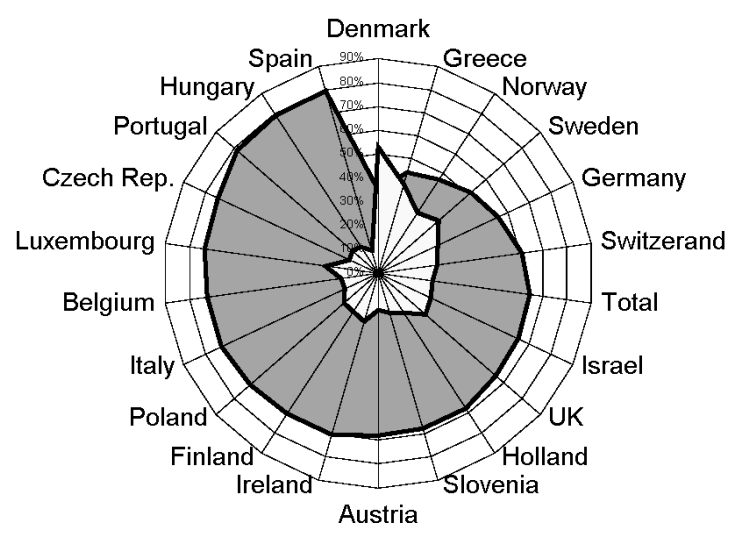

पDefinitely not $/$ Probably not

Source: Halman (2003)

Maybe this is because they do not believe in main political protagonists, finding that they are not very interested in what is really important for the people. In this case, along with the Slovenians, Greeks, Poles and Czechs, the Portuguese are among those who have fewer expectations that the politicians are truly interested in their opinions and act according to the needs of people like them. In other words, the distance between politicians and citizens, or the governing and the governed, expressed by a mix of indifference and disinterest, means an increasing lack of trust in political activity and political institutions, that is, in authority in general, which is very much the case of justice and the Court system.

Figure 19 Do you think that politicians in general care about what people like you think?

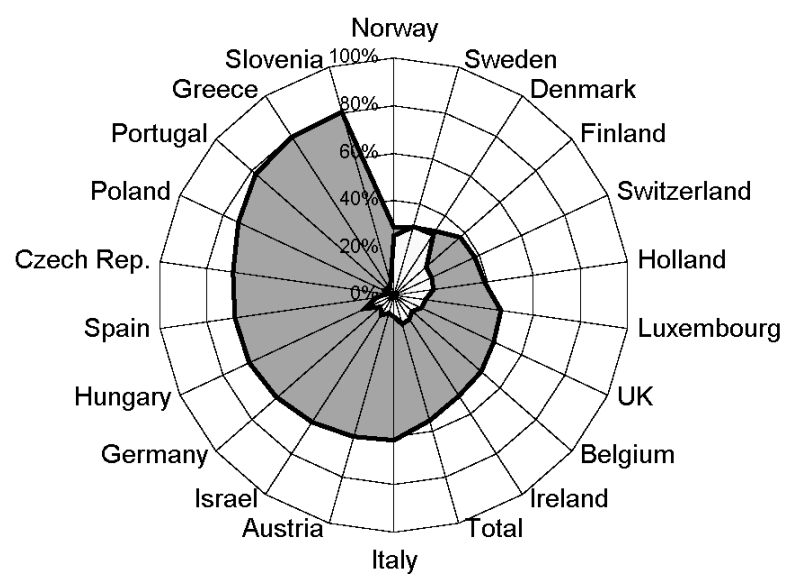
口Hardly any I very few

Source: Halman (2003) 
As a matter of fact, the graph of Figure 20 shows again that Portugal is much closer to the highest levels of lack of confidence in politicians. And once again, more confidence in politicians comes mostly from the Nordic countries. The same occurs in what concerns National Parliaments and Courts, which is much more serious, given the crucial role of these institutions for the health of democracy. ${ }^{5}$

Figure 20 Trust in politicians in Europe

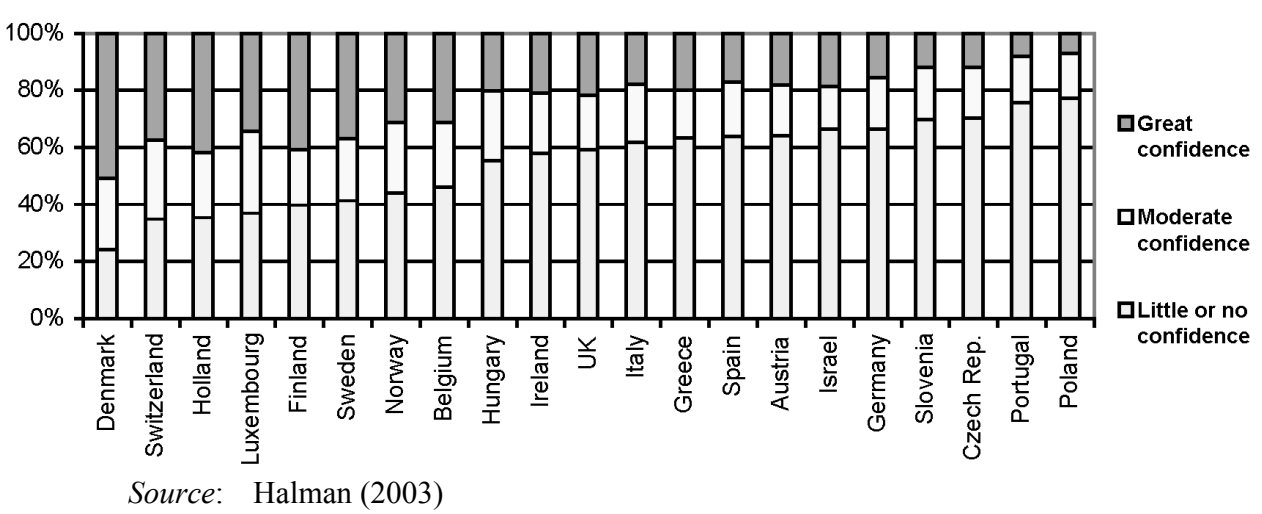

Discredit and lack of confidence in authorities or the distance to political power and decision making are the kinds of factors that greatly contribute to create a vicious circle of civic and political demobilisation. However, it does not necessarily mean that civil society is completely unresponsive to these issues. Actually, some surveys have shown that, though people are not very active in public issues, they do generally want to be informed about them and to retain the right to take part in decision making.

Actually, the graph in Figure 21 shows that over $63 \%$ of the Portuguese consider that playing an active role in decision making is both a duty and a right of all citizens, even when decisions do not affect them directly.

Another indicator of this trend is the increasing number of complaints to the Comissão de Acesso aos Documentos Administrativos (CADA) (Committee for the Access to Documentation of the Administration), which suggests a growing interest and mobilisation of citizens in actively defending their rights and collective interests. Actually, complaints to CADA quadrupled between 1997 and 2001, and most of complaints about access to administrative documents (33\%) were against local authorities (see Figure 22).

Figure 21 Opinion on the role of citizens in the decision making processes

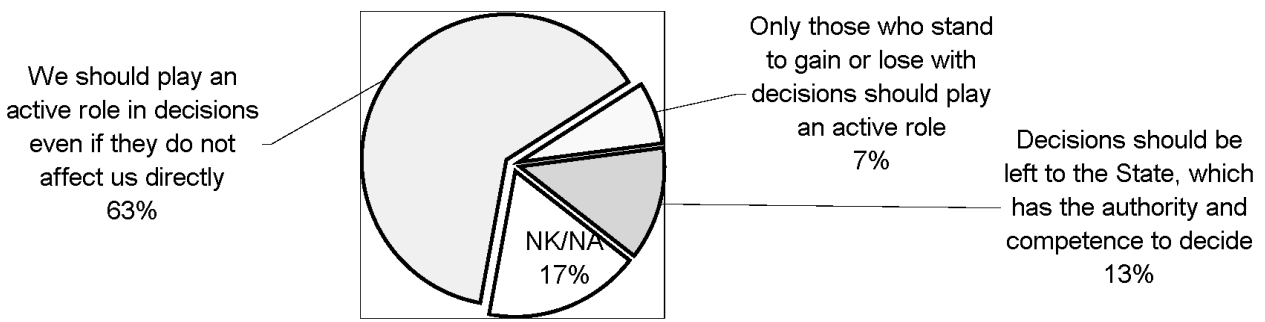

Source: Almeida (2004) 
Figure 22 Complaints to the Committee for the Access to Documentation of the Administration (CADA) - Portugal

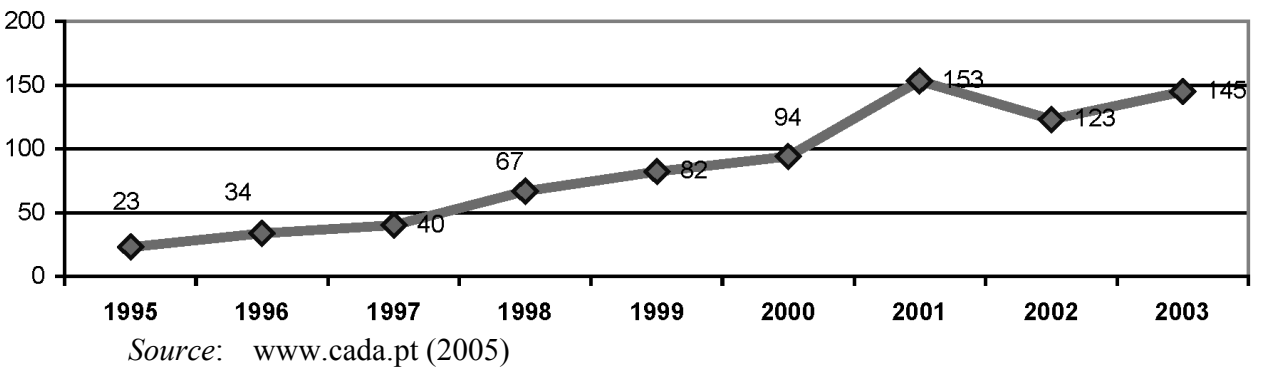

Considering most and widely different forms of civic and political participation, they seem not to relate to the daily practice of democracy by the Portuguese (Cf. CNADS, 2003). The old lack of democratic tradition and the long running authoritarian regime for the most part of 20th century, which meant around 40 years of prohibiting the people from any kind of participation in groups and politics, is often cited as a prime factor. However, one also has to consider the high levels of illiteracy currently prevailing in the country (again very close to the lowest levels of literacy among European countries), a factor that highly contributes to apathy and mistrust in collective action. Moreover, a culture of secrecy still prevails in public administration, where access to information is often blocked, if not by the mere incapacity of the system to respond to claims that participation requires ( $C f$. Cabral, 2003). As a consequence, the Portuguese population feels distanced from political power and the administration, hardly participating in ruling the community and in public affaires. That is, there is no confidence in collective action, no participation, and no part in decision making.

\section{Conclusions}

After all kinds of data were considered, the first conclusion is that post-Rio 92 initiatives and issues emerging in the world political agenda, in particular the Local Agenda 21, had less repercussion in European countries where democracy came later. Other priorities led political authorities and administrations to relegate sustainable development to secondary levels. The issue is that a strong commitment by administrations at the governmental level is a critical factor for the advancement of Agenda 21 at the local level.

Local Agenda 21 is essentially a process of democratic practicing, insofar as it involves sharing political competencies in decision making by the local authorities and, on the other hand, the mobilisation of all citizens and civil society organisations in the process. Thus, it is a course of action in which the willingness and openness of political leaders is as important as the ability of citizens to take the initiative of learning about and getting involved in public life. Moreover, it is vital for the success of Local Agenda 21 to enhance human resources at the highest and the lowest levels of the administration with capacity building to respond to this challenge. Effective mobilisation is not so much a case of ad hoc and momentary action (demonstrations, protests, etc.) as it is about the ability to collaborate, cooperate, and construct new models for running and ameliorating democracy. 
Where democracy is more recent and deep administrative reforms are still few (e.g., where high levels of bureaucracy still stand), problems of democratic entropy tend to rise, contributing to hindrance and delay of Local Agenda 21 processes. It is clearly the case in Portugal (as it seems to be also the case of many countries from the former Eastern block) where disenchantment with formal participation - be it through political parties or through other kinds conventional associations (e.g., trade unions) - and the practice of democracy and participation is far from achieving optimum levels.

This is the case for both decisionmakers at the local level and the citizenry in general, the former doubling as central authorities in raising obstacles to participation (see, e.g., the restrictions in access to information) and undermining the confidence of local population, while the latter have no confidence in their own ability to influence decisions, and thereby keep away from collective problems and the public sphere. Resorting to several kinds of public opinion surveys in different European countries, the evidence is that the lack of confidence in decisionmakers is a characteristic of this type of society and polity. Some reasons were suggested to explain this civic and political demobilisation for the case of Portugal, in particular, the high levels of illiteracy, the feeling that action by ones own initiative does not have any impact, and that distance from the authorities is insurmountable.

However, other forms of participation tend to rise and develop (e.g., debates, petitions, public consultations ...) showing that the people in this situation also want and have the potential to soon play a more active role. Moreover, these forms of participation and the will to participate suggest the local level is emerging as the more plausible and suitable scale for intervention by the citizenry. According to an extended survey (Almedia, 2004) of a sample of the Portuguese population, the opinion is that local authorities should have more influence in the politico-administrative domain at the central level. The fact is that while central-state scale of decision making is progressively becoming more European, that is, increasingly transferred to EU, people are turning again to communities and regions, that is, to the localities where they live, on political issues and protagonists whom they directly touch. The 'kingdom' of local authorities is therefore an ideal field of action for exercising citizenship, and qualitative changes can be expected from there. The will of the people to play a more active role and the conditions that allow the enhancement of civic participation and participatory processes, as the case of Local Agenda 21, look like having really reached a turning point.

This is why national programmes are necessary and urgent. They are able to provide the framework, impetus, and stimulus for LA21 processes. This has already proved effective in other contexts. However, in order to fully succeed, they still have to be anchored at the local level, so that policies of proximity are made possible and the knowledge of the field is guaranteed. They have to guarantee that measures are well adapted and fit to local realities, particularly to the will and needs of local populations. They have to take into account that Local Agenda 21 has to be clear and simple, and to point out to aspects understandable and visible in the daily life of the citizens. It has to contribute to increasing mutual confidence and trust between the governing and the governed. Discussing and debating different and complementary points of view in this context makes action and implementation of local policies more efficient.

Obviously, there is no single and unique solution, or miraculous prescription for Local Agenda 21, which in itself is a process of permanent experimentation, of trial and error. However, this is the nature of the challenge for the consolidation of sustainable development in the future. Experiences all over the world underline the reciprocal 
reinforcement of all components of the process: more availability of information and more openness from local administrations tend to guarantee more confidence among and from the citizens. And confidence is the basis for committed and motivated participation in causes for the quality of life and sustainable development within the community.

\section{References}

Almeida, J.F. (Ed.) (2004) Os Portugueses e o Ambiente: II Inquérito Nacional às Representações e Práticas dos Portugueses sobre o Ambiente, Celta, Oeiras.

Cabral, M.V. (2003) 'O exercício da cidadania política em Portugal', in Cabral, M.V., Vala, J. and Freire, J. (Eds.): Atitudes Sociais dos Portugueses: Trabalho e Cidadania, Lisbon, ICS/ISSP, pp.123-162.

CNADS (2003) Reflexão sobre o Acesso à Informação, à Participação Pública nos Processos de Tomada de Decisão e o Acesso à Justiça, Conselho Nacional de Ambiente e Desenvolvimento Sustentável/Fundação Calouste Gulbenkian, Lisboa.

Halman, L. (Ed.) (2003). European Values Study 1999/2000 (CD ROM), Cologne: Zentralarchiv für Empirische Sozialforschung/Tilburg University.

ICLEI (2002) Second Local Agenda 21 Survey, New York, United Nations Secretariat for the World Summit on Sustainable Development/International Council for Local Environment Initiatives.

Jowell, R. et al. (2003) European Social Survey 2002/2003: Technical Report, Centre for Comparative Social Surveys, City University, London.

Lafferty, W. (Ed.) (2001) Sustainable Communities in Europe. London: Earthscan.

Schmidt, L., Nave, J.G. and Guerra, J. (2005) Autarquias e Desenvolvimento Sustentável - Agenda 21 Local e Novas Estratégias Ambientais, Fronteira do Caos, Porto.

UNCED (1992) Agenda 21, 3-14 June, United Nations Conference on Environment and Development, Rio de Janeiro, Brazil.

\section{Notes}

${ }^{1}$ Portugal was ruled for around five decades (1926-1974) by an authoritarian regime, which similarly to General Franco's in Spain survived to the consolidation of democracies in Western Europe following the end of Second World War. Closed onto itself and resorting to a self-centred economic system, under the leadership and the tutelage of a single man (the dictator Salazar), whose followers gathered on a political party called União Nacional and a one-party political system, Portugal finished involving in a three front colonial war in the early 60's.

${ }^{2}$ The arrows indicate the trends for growth in the countries: $\boldsymbol{\lambda}$ : growing; $\mathbf{y}$ : in decline; $\leftrightarrow \rightarrow$ : stable situation.

${ }^{3}$ Eixo Atlantico is a jointly LA21 initiative by 9 municipalities in Northern Portugal and 9 in Galicia (Spain). Raia 21 joins municipalities of a depressed cross-border region in the Interior South of the Iberic Peninsula, 6 from Andalucia (Spain) and 6 from the Alentejo (Portugal).

${ }^{4}$ The ICLEI applied the survey to 633 local authorities in 113 countries in 2000 and 2001, aiming at listing and characterizing Local Agenda 21 processes around the world.

${ }^{5}$ The current situation of bureaucratic stifling and procedure delays also greatly contribute for the discredit of justice and the courts in Portugal. 